\title{
Translation, Adaptation and Exploration of Psychometric Properties of the Emotional Labor Scale (ELS) in a Sample of Psychologists
}

\author{
Mary Sandra Carlotto ${ }^{1}$ \\ Universidade do Vale do Rio dos Sinos, São Leopoldo, RS, Brazil \\ Sandra Yvonne Spiendler Rodriguez \\ Faculdade de Desenvolvimento do Rio Grande do Sul, Porto Alegre, RS, Brazil \\ Sheila Gonçalves Câmara \\ Universidade Federal de Ciências da Saúde de Porto Alegre, Porto Alegre, RS, Brazil
}

\begin{abstract}
Emotional labor is a worker's effort in regulating his or her emotions in an attempt to express socially desired emotions within the sphere of his or her profession. This study analyzed the adequacy of the original factor model of the Emotional Labor Scale (ELS) proposed by Brotheridge and Lee (2003), which assesses the duration, the frequency, the intensity, the variability, the depth and the superficiality of emotions in the workplace. The study comprised a sample of 518 psychologists from the state of Rio Grande do Sul, Brazil. Data was subjected to Confirmatory Factor Analysis, showing that the best fit indices were found in the distribution of four factors: frequency, intensity, variability and emotion regulation. Regarding reliability, satisfactory indices were found, ranging from .67 to .84 . Thus, the instrument is suitable for the assessment of emotional labor, allowing subsidizing promotion and prevention interventions for emotional management.
\end{abstract}

Keywords: Emotional labor, scales, factor analysis.

\section{Tradução, Adaptação e Exploração das Propriedades Psicométricas da Escala de Emoções no Trabalho (EET) em uma Amostra de Psicólogos}

\begin{abstract}
Resumo
O trabalho emocional diz respeito ao esforço do trabalhador em regular suas emoções na tentativa de expressar emoções socialmente desejadas no âmbito da sua profissão. Este artigo analisou a adequação do modelo fatorial original da Escala de Emoções no Trabalho (ETE) proposta por Brotheridge e Lee (2003), que avalia a duração, a frequência, a intensidade, a variabilidade, a profundidade e a superficialidade das emoções no contexto de trabalho. Participaram do estudo 518 psicólogos do estado do Rio Grande do Sul. Foi realizada Análise Fatorial Confirmatória, a qual demonstrou que os melhores índices de ajustamento foram encontrados na distribuição em quatro fatores: frequência, intensidade, variabilidade e regulação emocional. Quanto à fidedignidade, foram encontrados índices satisfatórios, variando de 0,67 a 0,84. Assim, o instrumento é indicado para a avaliação do trabalho emocional, permitindo subsidiar intervenções de promoção e prevenção da gestão emocional.
\end{abstract}

Palavras-chave: Trabalho emocional, escalas, análise factorial.

1 Mailing adress: Universidade do Vale do Rio dos Sinos, Programa de Pós-Graduação em Psicologia, Av. Unisinos, 950, Cristo Rei, São Leopoldo, RS, Brazil 93022-970. E-mail: mscarlotto@gmail.com 


\section{Traducción, Adaptación y Exploración de las Propiedades \\ Psicométricas de la Escala de Trabajo Emocional (ETE) en una Muestra de Psicólogos}

\section{Resumen}

El trabajo emocional se refiere al esfuerzo del trabajador en regular sus emociones en lo intento de expresar emociones socialmente deseadas en el ámbito de su profesión. Este artículo analizó la adecuación del modelo factorial original de la Escala de Emociones en el Trabajo (EET) propuesta por Brotheridge y Lee (2003), que evalúa la duración, la frecuencia, la intensidad, la variabilidad, la profundidad y la superficialidad de las emociones en el contexto de trabajo. Participaron del estudio 518 psicólogos del estado del Rio Grande do Sul, Brasil. Fue realizada Análisis Factorial Confirmatoria, la cual demostró que los mejores índices de ajustamiento fueron encontrados en la distribución en cuatro factores: frecuencia, intensidad, variabilidad y regulación emocional. Cuanto a la fiabilidad, fueron encontrados índices satisfactorios, variando de .67 a .84. Así, el instrumento es indicado para la evaluación del trabajo emocional, permitiendo subsidiar intervenciones de promoción y prevención de la gestión emocional.

Palabras clave: Trabajo emocional, escalas, análisis factorial.

The hegemony of rational administration principles, widely accepted and disseminated throughout the world, persisted until the beginning of the $20^{\text {th }}$ century, causing labor organizations to neglect the presence of emotions within this context. Only after the Human Relations Theory that the Taylorist/Fordist management model of labor organization started to be questioned, with an emphasis on the importance of comprehending the components of human behavior and the psychosocial needs of man in the labor context (Matos \& Pires, 2006).

Thegreatestcontributiontotheunderstanding of emotions in the workplace occurred from a research conducted by Hochschild (1983) with flight attendants. It showed that workers, especially those who perform customer services, need to manage their feelings in order to express the emotions required in the exercise of a professional role, even though this effort is not clear to them. In this sense, the author defined Emotional Labor (EL) as a worker's effort in regulating his or her emotions in an attempt to express socially desired emotions, an effort that can cause emotional dissonance.

Emotional dissonance is the degree of incompatibility existing between expressed emotions and the real feelings of a subject. A worker, seeking to deal with dissonance, appeals to two types of representations: superficial and deep. Superficial representation consists of a decrease in the authentic display of feelings in favor of an emotional mask manifested through facial expressions, while deep representation is the effort made toward searching inside oneself for the adequate feelings to a certain situation, or toward changing feelings regarded as inadequate to a certain context (Brotheridge \& Lee, 2003).

It is important to highlight that, for the characterization of EL, it is necessary that: there are job demands in terms of face-to-face and voice-to-voice interactions; emotions are expressed to influence the emotions, attitudes and behaviors of other people; interpersonal relationships are part of the job; there are appropriate norms for each situation (Hochschild, 1983). Organizational norms about implicit or explicit emotions, just as the emotional demands of the job, and the duty to express positive emotions while working, have an influence on the health of professionals (Mukiur, 2012), being associated with organizational losses (Brotheridge, 2006; Hochschild, 1983; Nguyen, Groth, \& Johnson, 2013) and individual losses (Brotheridge, 2006). From the perspective of organizations, emotional well-being is related to 
increase in productivity (Brotheridge, 2006), less turnovers and absenteeism (Gracia, Martínez, Salanova, \& Nogareda, 2004). From the worker's viewpoint, emotional well-being has to do with better physical and psychic health conditions (Brotheridge, 2006), greater commitment and satisfaction with the job (Gracia et al., 2004) and less intention of quitting it (Ogungbamila, Balogun, Ogungbamila, \& Oladele, 2014). EL has been related to illnesses, such as the Burnout Syndrome (Bakker \& Heuven, 2006; Gracia et al., 2004), depression (Wieclaw et al., 2008) and several psychosomatic disorders (Gracia et al., 2004). The main requirement of EL refers to certain emotional skills and competences for an adequate functional performance in interpersonal relationships. In this sense, the prevention of possible negative implications on the worker's health is important (Gracia et al., 2004).

EL has caught the eyes of the scientific community, and many studies have been conducted with several professional categories, such as caregivers of children (Lee \& Brotheridge, 2011), flight attendants (Hur, Moon, \& Jun, 2013), physicians (Lee, Lovell, \& Brotheridge, 2010), service providers (Lam \& Chen, 2012), police officers (Bakker \& Heuven, 2006) and teachers (Philipp \& Schüpbach, 2010). Various scales for EL assessment have been developed based on different approaches for the measuring of the construct, as the Frankfurt Emotional Work Scale - FEWS (Zapf, Vogt, Seifert, Mertini, \& Isic, 1999), the Emotional Labor Inventory - ELI (Mann, 1999), the Emotional Labor Scale - ELS (Schaubroeck \& Jones, 2000), the Integrative Emotional Work Inventory - IEWI (Strazdins, 2000) and the Emotional Labor Scale - ELS (Brotheridge \& Lee, 2003). The later, unlike the other scales available, assesses superficial and deep representations, allowing for measuring the emotional management process carried out by professionals.

The procedures for the construction of the ELS generated 40 items that were reviewed according to feedback provided by members of the body of teachers of two Canadian universities, and to discussions with workers of the service sector. After that, a pre-test was conducted in a sample of Canadian Business students. Based on the analysis of the results, many items were excluded due to their complexity, to the low levels of variance identified and to the high levels of asymmetry and kurtosis, causing the scale to be reduced to 19 items, measured by a 5-point scale ranging from never to always. This version of the scale was applied to a sample of 296 college students who worked in several activities of provision of services. An exploratory factor analysis was carried out, reducing the scale to 15 items, which explained $60.5 \%$ of the construct variance, with alphas ranging from .58 to .85 (Brotheridge \& Lee, 2003). A new study was conducted by the authors with 238 professionals of the service industry with more time of experience. A confirmatory factor analysis was performed, revealing adequate adjustment indices, and confirming the theoretical model and number of items of the previous version, obtaining alpha values that ranged from .74 to .88 .

The factorial structure of the scale has been recently confirmed in a validation study conducted in Spain by Picardo, López-Fernández and Hervás (2013), which identified adequate fit indices, confirming the theoretical model of the original version. The structure was formed by duration, frequency, intensity, variety, surface acting and deep acting was confirmed in this study achieving a very good fit to data $\left[\mathrm{X}^{2}=\right.$ $69,35(76 d f) p=.69 ; \mathrm{RMSEA}=.00 ; \mathrm{CFI}=1.00$; $\mathrm{GFI}=.93]$.

Although there are studies in Brazil that approach EL, it was not possible to identify, on the main databases (Health Virtual Library, Periódicos Eletrônicos de Psicologia [PePSIC], Pubmed and Scientific Electronic Library Online [SciELO]), studies that assessed the psychometric properties of the ELS in this context. In the light of above, the objective of this study was to adapt and study the ELS validity in psychologists.

\section{Method}

\section{Participants}

The sample was composed of 518 psychologists who had been working in the state of Rio Grande do Sul for more than one year. Most 
of them are women $(77.6 \%)$, in a stable union $(60.2 \%)$, without children $(57.5 \%)$. The age of the participants varied from 23 to 65 years old $(M=34.7 ; S D=8.4)$. On average, they have been performing this activity for more than 10 years $(S D=8.9)$, with a variation of 01 to 40 years. Most of them work exclusively with psychology $(74 \%)$, in one single area $(58 \%)$ and earn between 3 and 6 minimum wages (51.6\%).

\section{Instruments}

The ELS was developed by Brotheridge and Lee (2003), based on a theoretical model proposed by Hochschild (1983). The scale is composed of 15 items, one item referring to the duration of the interaction (A typical interaction with customers lasts about minutes) and 14 items distributed into 5 subscales: (a) Frequency (I display specific emotions required by my job); (b) Intensity (I display intense emotions at work); (c) Variety (I display many different kinds of emotions at work); (d) Superficial representation (I resist expressing my true feelings at work); and (e) Deep representation (I really try to experience the emotions I should display at work). The items are assessed through a 5-point Likert scale ranging from never (1) to always (5). The construction of the ELS considered its easy comprehension, neutral writing and short sentences. The original scale presents satisfactory Cronbach's alpha values varying from .74 to .91 .

For the characterization of the participants, a questionnaire with sociodemographic data was used (sex, age, marital status, children, and remuneration) and work-related data (type of education, time of education, weekly workload, number of daily services, time of activity, exclusive work with psychology).

\section{Translation and Adaptation}

The procedure for the validation of the instrument was authorized by its authors, represented by the first author, Celeste Brotheridge. From the original version, in English, the Brazilian adaptation of the ELS complied with the methodological standards recommended by the
International Tests Commission (ITC) for the adequate adaptation of instruments to other cultures (Muñiz, Elosua, \& Hambleton, 2013). The translation and back-translation were done by two translators fluent in English and Brazilian Portuguese. In the assessment of the semantic equivalence, it was verified that the reference meaning presented good results, as all items obtained, in the back-translations, between $90.0 \%$ and $100 \%$ of agreement in this criterion (Reichenheim \& Moraes, 2007).

The final version in Brazilian Portuguese was subjected to a pilot test, for semantic assessment, with 30 psychologists of a higher education institution who do not belong to the population studied. The subjects were asked to manifest aspects related to the understanding of words and enunciations. At this stage, there was no need for changing any item.

\section{Procedures of Data Collection and Analysis}

The study data was collected by means of an online research. For the recruitment of participants, the technique of Respondent Driven Sampling (RDS) was adopted, in which the first participants ( $1^{\text {st }}$ wave) send an invitation to new participants ( $2^{\text {nd }}$ wave $)$, until the desired size of the sample is achieved (Goel \& Salganik, 2009)

The psychologists received an invitation by e-mail to participate in the research, and those who accepted it manifested their agreement by signing a free consent form, in accordance with the ethical guidelines of Resolution 466 of the National Council of Health concerning the conduction of researches involving humans (Brazilian Ministry of Health, 2012). The study was approved by the Ethics and Research Committee of Pontificia Universidade Católica do Rio Grande do Sul (PUC/RS) under Legal Opinion No 445847.

The database was typed and, then, analyzed through the software SPSS, version 17.0. First, descriptive analyses of exploratory character were carried out for the assessment, in the database, of the distribution of the items and 
the identification of extremes. In order to verify the five-dimension model of the ELS, a Confirmatory Factor Analysis (CFA) was performed, maximum likelihood method, using the statistical software AMOS 17.0. The main reference values considered for the acceptance of the model were CFI $\geq .95$ and RMSEA $\leq .05$ (Byrne, 2001; Hooper, Coughlan, \& Mullen, 2008). Reliability was assessed by means of the Cronbach's alpha method.

\section{Results}

\section{Descriptive Statistics}

The descriptive statistics of the ELS can be seen in Table 1. The highest mean was that of item 05 (I adopt certain emotions required as part of my job), which belongs to the same dimension $(M=4.01)$. The dimension that presented the lowest mean was Variability, and item 13
(I really try to experience the emotions I should display), belonging to this dimension, presented the lowest mean $(M=2.37)$.

In relation to the corrected item-total correlation, most of the items obtained values higher than $r=.50$. Only item 02 , belonging to the Frequency subscale, obtained correlation below .50. As for the internal consistency coefficient, it was verified that the suppression of item 02 (Frequency) and 14 (Depth) contributed to the elevation of the Cronbach's alpha and its respective subscales.

Regarding asymmetry, only items 05 and 07 (Frequency) presented higher values. Items 02, 05 and 07 (Frequency), 11 (Variability), 04 and 15 (Depth) presented negative asymmetry. The other items had positive asymmetry. Items 05 and 07 presented values that exceeded the interval of \pm 1 in asymmetry. Alpha values ranged from .67 to .84 .

Table 1

Descriptive Statistics and Internal Consistency of Items and Dimensions of Emotional Labor Scale -ELS $(\mathbf{n}=518)$. RS, 2014

\begin{tabular}{|c|c|c|c|c|}
\hline Subescale/Item & $M(S D)$ & $\begin{array}{l}\text { Corrected } \\
\text { item-scale } \\
\text { Correlations }\end{array}$ & Skewness & $\begin{array}{l}\text { Alpha } \\
\text { if item } \\
\text { deleted }\end{array}$ \\
\hline Frequency $(\alpha=.67)$ & $4.01(0.61)$ & & -0.75 & \\
\hline 2 & $4.06(0.72)$ & .38 & -0.91 & .69 \\
\hline 5 & $4.07(0.80)$ & .56 & -1.18 & .46 \\
\hline 7 & $3.94(0.84)$ & .50 & -1.07 & .53 \\
\hline Intensity $(\alpha=.78)$ & $2.30(0.81)$ & & 0.64 & \\
\hline 3 & $2.41(0.85)$ & .64 & 0.41 & - \\
\hline 9 & $2.19(0.93)$ & .64 & 0.13 & - \\
\hline Variability $(\alpha=.84)$ & $2.54(0.91)$ & & 0.36 & \\
\hline 6 & $2.88(1.07)$ & .64 & 0.02 & .83 \\
\hline 11 & $2.38(1.05)$ & .73 & -0.57 & .74 \\
\hline 13 & $2.37(1.02)$ & .73 & 0.62 & .75 \\
\hline Emotion regulation $(\alpha=.79)$ & $2.24(0.99)$ & & -0.25 & \\
\hline 04 & $3.32(1.25)$ & .66 & -0.49 & .71 \\
\hline 10 & $3.41(1.12)$ & .66 & 0.65 & .72 \\
\hline 14 & $2.65(1.50)$ & .53 & 0.26 & .80 \\
\hline 15 & $3.60(1.14)$ & .61 & -0.83 & .74 \\
\hline
\end{tabular}




\section{Confirmatory Factor Analysis}

First, the original model that established relationship between all five factors was tested. The indices of the model, however, were not satisfactory (Hooper et al., 2008; Table 2).

This model presented elevated correlation between the factors Superficial and Deep representation $(r=.82)$, indicating that both could be analyzed as a single factor. In addition, the alphas of both of the factors, separately, were unsatisfactory. Thus, the choice was to unify these two factors into one. Considering the alpha coefficient, items 8 and 12 were excluded. It was also verified that the dimensions related to the same construct. The exclusion of these two items enabled a satisfactory adjustment of the model. The path diagram is shown in Figure 1.

Table 2

Model Adjusted for Emotional Labor Scale (ELS)

\begin{tabular}{lccccccc}
\hline Model & $X^{2}$ & $d f$ & RMSEA $_{(90 \% \mathrm{Cl})}$ & GFI & NFI & CFI & AIC \\
\hline $\mathrm{M}_{1}$ (5 factors) & 414.200 & 67 & $.100[.091, .109]$ & .905 & .850 & .870 & 490.207 \\
$\mathrm{M}_{2}$ (4 factors) & 157.420 & 48 & $.066[.055, .078]$ & .954 & .932 & .951 & 217.420 \\
\hline
\end{tabular}

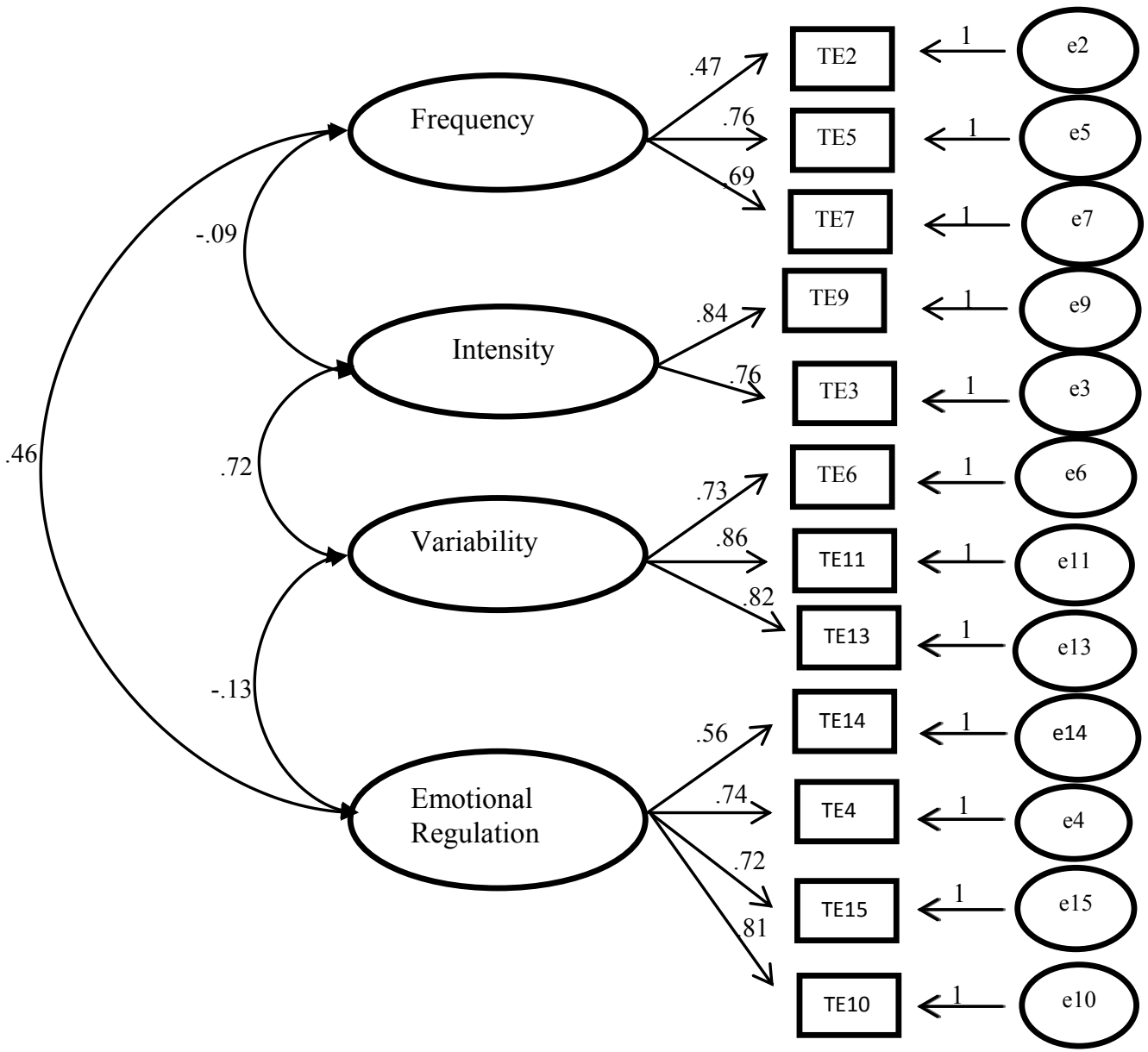

Figure 1. Results of factorial model for Emotional Labor Scale - ELS (n=518). Standardized estimates.

\section{Discussion}

This study aimed to assess the factorial structure of the ELS in a sample of psychologists, through the Confirmatory Factor Analysis.
The results did not corroborate the hypothesized model of five factors, according to the original one of the scale (Brotheridge \& Lee, 2003), but rather an alternative model of four factors with reduction of items. The factors identified were 
Frequency, Intensity, Variability and Emotional representation. The model obtained may be different from the original one because, in this study, the sample was composed of only one professional category, which presents, necessarily, emotional labor expectations, unlike the sample used in the original study, involving different types of professionals.

Thus, the original dimensions Superficial representation and Deep representation were unified, generating a new dimension called Emotional regulation, considering that the latter can comprehend both superficial and deep emotions (Grandey, 2000). Such result may be due to the characteristics of the professional sample studied. Psychologists usually present greater emotional sensitivity and proximity, since the establishment of affective bonds is a fundamental component of their job, which involves the handling of psycho-affective problems (Jacques, Borges, Heloani, \& Cassiolato, 2011).

From the results of the adequacy of the psychometric properties, it can be affirmed that the final model obtained suits the EL assessment in psychologists. The values of the corrected itemtotal correlation were high, evidencing that every dimension of the ELS can be considered as a linear function of the items that compose it. The values obtained for asymmetry indicate data adequacy. The highest values were identified in items $05(A s=-1.18)$ and $07(A s=-1.07)$, which belong to the Frequency dimension. According to Miles and Shevlin (2005), acceptable asymmetry values need to be contained in the interval of \pm 1 so that it can be concluded that the model has normal distribution. To the authors, the asymmetry presented by items 5 and 7 does not hinder the normality of the data. Item 2 is that with the lowest corrected item-total correlation in comparison with all of the others of the scale, and its exclusion would contribute to only a slight increase in the alpha of the Frequency dimension; for this reason, the choice was to keep it.

The Cronbach's alpha values obtained, satisfactory in every dimension (Tabachnick \& Fidell, 2001), allied to the semantic coherence of the set of items, allow considering that all of them contribute to the establishment of the construct concerning the EL assessment. It is worth highlighting that, in the Spanish adaptation (Picardo et al., 2013), the Frequency dimension was the one that presented the lowest value, both below the original one (Brotheridge \& Lee, 2003) that found an alpha of .75.

This study assessed the original version of the scale (Brotheridge \& Lee, 2003), and the Confirmatory Factor Analysis corroborated, in part, the initial theoretical structure of five factors. The model corroborated four of the five factors.

About the correlations between the dimensions, Intensity and Emotional regulation presented the lowest correlation $(r=.02 ; p \leq .05)$, positive, and the highest correlation, positive as well, between Intensity and Variability $(r=.51$; $p \leq .05)$. All items showed significant factorial loading. The lowest value was obtained for item $02(\lambda=0.56)$.

This study aimed at an initial assessment of the instrument in Brazil, based on its original structure of 15 items; with the fusion of two dimensions, the adapted instrument comprised 12 items. In this sense, it is worth stressing that the several validity aspects of the instrument showed satisfactory results, indicating that the ELS has psychometric properties that are adequate to the study of EL in psychologists. The instrument, thus, can contribute to the assessment of emotional labor, since this is an important aspect of the occupational health of these professionals, allowing subsidizing promotion and prevention interventions for emotional management.

The study presents some limitations that should be taken into consideration. The first is that the participants are, mostly, female. Although this data is compatible with the reality of the job of a psychologist, which, traditionally, is predominantly performed by women, this aspect is important, as men and women can differ in terms of the frequency, the intensity, the variability and the regulation of emotions involved in the professional activity.

From the results found and the limitations of this study, new investigations on the validity of the ELS should be conducted with a stratified sample, in order to verify the behavior of the instrument by sex. In addition to the assessment 
of this variable, the investigation with workers of different professional categories, especially in the field of health and education, in different economic and sociocultural contexts, will contribute to the comprehension of the stability of the instrument. According to the proposal of the original study on the ELS validation, it is interesting that studies can assess the relations of the scale with variables like emotional exhaustion and positive and negative affections.

\section{References}

Bakker, A. B., \& Heuven, E. (2006). Emotional dissonance, burnout, and in-role performance among nurses and police officers. International Journal of Stress Management, 13(4), 423440. doi:10.1037/1072-5245.13.4.423

Brazilian Ministry of Health. (2012). Resolution $N^{o}$. 466, of 12 December 2012. Retrieved from http:// conselho.saude.gov.br/resolucoes/2012/466 english.pdf

Brotheridge, C. M. (2006). A review of emotional labour and its nomological network: Practical and research implications. Ergonomia IJE \& HF, 28, 295-309.

Brotheridge, C. M., \& Lee, R. T. (2003). Development and validation of the Emotional Labour Scale. Journal of Occupational and Organizational Psychology, 76(3), 365-379. doi:10.1348/096317903769647229

Byrne, B. M. (2001). Structural equation modeling with Amos: Basic concepts, applications, and programming. New York: Springer.

Goel, S., \& Salganik, M. J. (2009). Respondentdriven sampling as Markov chain Monte Carlo. Statistics in Medicine, 28(17), 2202-2229. doi:10.1002/sim.3613

Gracia, E., Martínez, I M., Salanova, M., \& Nogareda, C. (2004). Nota técnica de prevenciónel trabajo emocional: concepto y prevención. Madrid, España: Ministerio de Trabajo. Recuperado en http://www.insht.es/InshtWeb/Contenidos/ Documentacion/Fichas Tecnicas/NTP/ Ficheros/701a750/ntp_720.pdf

Grandey, A. (2000). Emotion regulation in the workplace: A new way to conceptualize emotional labor. Journal of Occupational Health Psychology, 5(1), 95-110. doi:10.1037/10768998.5.1.95
Hochschild, A. R. (1983). The managed heart: Commercialization of human feeling, with a new afterword. Berkeley, CA: University of California Press.

Hooper, D., Coughlan, J., \& Mullen, M. (2008). Structural equation modeling: Guidelines for determining model fit. Electronic Journal of Business Research Methods, 6(1), 53-60.

Hur, W. M., Moon, T. W., \& Jun, J. K. (2013). The role of perceived organizational support on emotional labor in the airline industry. International Journal of Contemporary Hospitality Management, 25(1), 105-123. doi:10.1108/09596111311290246

Jacques, M. D. G., Borges, L. D. O., Heloani, R., \& Cassiolato, R. (2011). Saúde/Doença no trabalho do psicólogo: A Síndrome de Burnout. In A. V. B. Bastos \& S. M. G. Gondin (Eds.), O trabalho do psicólogo no Brasil (pp. 338-358). Porto Alegre, RS: Artmed.

Lam, W., \& Chen, Z. (2012). When I put on my service mask: Determinants and outcomes of emotional labor among hotel service providers according to affective event theory. International Journal of Hospitality Management, 31(1), 3-11. doi:10.1016/j.ijhm.2011.04.009

Lee, R. T., \& Brotheridge, C. M. (2011). Words from the heart speak to the heart: A study of deep acting, faking, and hiding among child care workers. Career Development International, 16(4), 401-420. doi:10.1108/13620431111158805

Lee, R. T., Lovell, B. L., \& Brotheridge, C. M. (2010). Tenderness and steadiness: Relating job and interpersonal demands and resources with burnout and physical symptoms of stress in Canadian physicians. Journal of Applied Social Psychology, 49(99), 2319-2342.

Mann, D. G. (1999). The species concept in diatoms. Phycologia, 38(6), 437-495. doi:10.2216/ i0031-8884-38-6-437.1

Matos, E., \& Pires, D. (2006). Teorias administrativas e organização do trabalho: De Taylor aos dias atuais, influências no setor saúde e na enfermagem. Texto \& Contexto - Enfermagem, 15(3), 508-514. doi:10.1590/S010407072006000300017

Miles, J., \& Shevlin, M. (2005). Applying regression and correlation: A guide for students and researchers. London: Sage. 
Mukiur, R. M. (2012). El constructo de trabajo emocional y su relación con el síndrome del desgaste profesional. International Journal of Psychology and Psychological Therapy, 12(2), 219-244.

Muñiz, J., Elosua, P., \& Hambleton, R. K. (2013). Directrices para la traducción y adaptación de los tests: segunda edición. Psicothema, 25(2), 151157. doi:10.7334/psicothema2013.24

Nguyen, H., Groth, M., \& Johnson, A. (2013). When the going gets tough, the tough keep working: Impact of emotional labor on absenteeism. Journal of Management, 40(5), 1-29. doi:10.1177/01 49206313490026

Ogungbamila, B., Balogun, A.G., Ogungbamila, A., \& Oladele, R. S. (2014). Job stress, emotional labor, and emotional intelligence as predictors of turnover intention: Evidence from two service occupations. Mediterranean Journal of Social Sciences, 5(6), 351-357. doi:10.5901/mjss.2014. v5n6p351

Philipp, A., \& Schüpbach, H. (2010). Longitudinal effects of emotional labour on emotional exhaustion and dedication of teachers. Journal of Occupational Health Psychology, 15(4), 494. doi:10.1037/a0021046

Picardo, J. M., López-Fernández, C., \& Hervás, M. J. A. (2013). The Spanish version of the Emotional Labour Scale (ELS): A validation study. Nurse Education Today, 33(10), 1130-1135.

Reichenheim, M. E., \& Moraes, C. L. (2007). Adaptação transcultural de instrumentos de aferição epidemiológicos: Uma proposta de operacionalização. Revista de Saúde Pública, 41, 665-673.
Schaubroeck, J., \& Jones, J. R. (2000). Antecedents of workplace emotional labor dimensions and moderators of their effects on physical symptoms. Journal of Organizational Behavior, 21(2), 163-183. doi:10.1002/ (SICI) 1099-1379(200003)21:2<163::AIDJOB37>3.0.CO;2-L

Strazdins, L. M. (2000). Integrating emotions: Multiple role measurement of emotional work. Australian Journal of Psychology, 52(1), 41-50. doi:10.1080/00049530008255366

Tabachnick, B. G., \& Fidell, L.S. (2001). Using multivariate analysis (4 ${ }^{\text {th }}$ ed.). Boston, MA: Allyn and Bacon.

Wieclaw, J., Agerbo, E., Mortensen, P. B., Burr, H., Tuchsen, F., \& Bonde, J. P. (2008). Psychosocial working conditions and the risk of depression and anxiety di- sorders in the Danish workforce. BMC Public Health, 7(8), 280. doi:10.1186/1471-2458-8-280

Zapf, D., Vogt, C., Seifert, C., Mertini, H., \& Isic, A. (1999). Emotion work as a source of stress: The concept and development of an instrument. European Journal of Work and Organizational Psychology, 8, 371-400.
Recebido: 26/01/2015

$1^{a}$ revisão: $15 / 04 / 2015$

$2^{a}$ revisão: $27 / 04 / 2015$

Aceite final: 22/05/2015 